\title{
POLITICAL AND ECONOMIC GOVERNANCE: A COMPARATIVE ANALYSIS OF EASTERN EUROPEAN COUNTRIES AND UKRAINE
}

\author{
Tamara Latkovska', Lyubov Bila-Tiunova²
}

\begin{abstract}
The presented work is an attempt to compare the quality of governance in non-EU states in the Western Balkans and Eastern Europe with which the EU Association Agreements have been concluded, and Ukraine, including aspects of the impact of the DCFTA (Deep and Comprehensive Free Trade Areas). The most important issues are the interpretation of the results, the equality of countries, and the political consequences that may arise after the progression and the rapid pace of the member countries of the DCFTA towards the countries of the Balkan region. The identified countries seek full membership in the EU. Although the EU distinguishes between these countries, it recognizes "European prospects", that is, membership in the EU, the commitments to adopt or approach EU laws and policies, made by both groups of countries, have much in common. This makes the comparison between the countries of the Balkan region and the member states of the DCFTA a sound and politically significant one. Such comparison is facilitated by numerous sources, qualitative assessments, and official ratings. Figuratively by analytical indicators, the countries can be divided into the first group of leading countries (Serbia and Montenegro) for which in February 2018 the European Commission proposed to consider 2025 as the possible date of accession to the EU. The second group (Albania and Macedonia), for which the date of accession negotiations is conditionally open in 2019. The third group includes Bosnia and Herzegovina, Kosovo, for which there are no dates, and Turkey, the negotiations with which are suspended. For comparison, if we take both political and economic indicators of Ukraine, it is approximately equal to the Balkan states of the second group and outstrips the states of the third group. The prospect of EU membership was recognized as the strongest external factor of internal political changes in the countries surrounding the EU. One of the most striking trends is the steady decline in the standards of political governance in all countries, for which the EU expands its membership perspective. One of the main manifestations of poor governance in the broader neighbourhood is the widespread corruption and impunity of officials. Weak rule of law and ineffective law enforcement bodies have become common practice in all different states and have allowed current officials to act impunity during their term of office. The identified results challenge the assumption dominating in political and scientific circles that a credible prospect of EU membership is steadily generating an internal environment conducive to democratic changes. The effectiveness of economic governance was assessed by the indicators of competitiveness of the national economy (Global Competitiveness Index, Corruption Perceptions Index, Human Development Index, Ease of Doing Business Index, Index of Economic Freedom, Index of Globalization, SEDA (Sustainable Economic Development Assessment)); GDP dynamics; the volume of foreign direct investment; economic activity of the population. In practice, the EU applies an increasing number of common economic policy instruments for the Balkans and member countries of the DCFTA, in spite of the political (or rhetorical) differentiation between countries, given the categorization of membership prospects. The convergence of the actual EU policy has taken place. The Association Agreements and the DCFTA have raised the level of political and economic governance in Georgia, Moldova, and Ukraine at the level of the Balkan countries while the expansion process for the Balkan countries has not advanced.
\end{abstract}

Key words: European studies, DCFTA, political governance, economic governance, Baltic States, democratic choice.

JEL Classification: O19, F15, F42, R38, R50

\footnotetext{
Corresponding author:

${ }^{1}$ National University “Odessa Law Academy”, Ukraine.

E-mail: tamaralatkovska@gmail.com

ORCID: https://orcid.org/0000-0003-3159-5994

${ }^{2}$ National University “Odessa Law Academy”, Ukraine.

E-mail: bilatiunova@gmail.com

ORCID: https://orcid.org/0000-0001-7886-793X
} 


\section{Introduction}

The presented work is an attempt to compare the quality of governance in non-EU states in the Western Balkans and Eastern Europe, with which the EU Association Agreements have been concluded, and Ukraine, including aspects of the impact of the DCFTA (Deep and Comprehensive Free Trade Areas).

The most important issues are the interpretation of the results, the equality of countries, and the political consequences that may arise after the progression and the rapid pace of the member countries of the DCFTA towards the countries of the Balkan region. The main characteristics include: Direct neighbourhood/proximity to the EU; The overall goal of full membership in the EU; Granting of the right to European democracies to apply for membership in the EU (Article 49 of the Lisbon Treaty); Progressive adaptation of EU political and economic regulations and standards; Comparability of results of political and economic governance. Analytical items allow revealing some anomalies in the structural development of countries, how the EU should react, and which scenarios it will choose according to the countries of the Balkan region and the member countries of the DCFTA.

The identified countries seek full membership in the EU. Although the EU distinguishes between these countries, it recognizes "European prospects", that is, membership in the EU, the commitments to adopt or approach EU laws and policies, made by both groups of countries, have much in common. This makes the comparison between the countries of the Balkan region and the member states of the DCFTA a sound and politically significant one (Richter, Solveig, 2012).

Such comparison is facilitated by numerous sources, qualitative assessments, and official ratings. The emphasis is made on regular annual reports on the development of the Balkan region and Turkey prepared by the EU institutions and research papers published by CEPS. In general, these assessments show that political and economic governance in the countries is comparable, even taking into account the wide range of country ratings.

\section{The methodology of research}

The Deep and Comprehensive Free Trade Area (DCFTA) between Ukraine and the EU is a broad-based trade agreement aimed at reducing and eliminating tariffs applied by the parties to goods, liberalizing access to the services market, and bringing Ukrainian business rules and regulations in line with EU rules and regulations for the purpose of free movement of goods and services between the two parties and mutual nondiscriminatory attitude towards companies, goods, and services on the territory of Ukraine and the EU.

In January 2016, the Deep and Comprehensive Free Trade Area (DCFTA) between Ukraine and the EU, which is a part of the Association Agreement, signed in June 2014, began to operate. The introduction of DCFTA has led to a reduction in import duties in Ukraine for EU goods. At the same time, Ukrainian exporters have already received liberalized access to the EU market through Autonomous Trade Preferences (ATP) from the EU, which operated during the past two years. In 2019, the tariff protection of the EU market for Ukrainian exporters did not change significantly, since according to the ATP, they were already subject to import duties and tariff quotas in the $\mathrm{EU}$ as foreseen in the Agreement for the first year of the DCFTA. Therefore, the achievements in 2016 can be expected by means of the use of previously unused opportunities (due to low demand in the EU, non-compliance with EU standards), as well as the reduction of non-tariff barriers to the EU market. In order to inform Ukrainian entrepreneurs about what will help them to develop their own business in European markets, the Delegation of the European Union to Ukraine has launched a new UopenEU project in social networks. It is an additional information resource about innovations and opportunities that will appear in the Ukrainian business after the entry into force of the DCFTA.

The conducted analytical study found that prospects for joining the EU should be determined by a threestep methodology. In February 2018, the European Commission proposed to consider 2025 as the possible date of the accession of Serbia and Montenegro, which means recognizing these two countries as leaders in the Balkans (or the first league), even if the EU Council does not approve this date. The second league was determined by the Council in June 2018, when 2019 was designated as a possible, conditional date for the opening of negotiations on the accession of Albania and Macedonia. While the third league - the entry of Bosnia and Kosovo, for which there are no dates, and Turkey, negotiations with which are suspended. For comparison, if we take both political and economic indicators, Ukraine is approximately equal to the Balkan states of the second league and outstrips the states of the third league. This is a general picture that has an obvious political significance, although there remains plenty of space for discussion of many indicators (Balkans in Europe Policy Advisory Group (BiEPAG), 2017; European Commission, 2018).

The general picture places in question the EU's objectivity in expanding its membership prospects for the Balkan group but denies it for the group of states of the DCFTA. It also requires a more thorough consideration of the overall assumption that membership incentives determine the effectiveness of the reform processes and the degree of convergence of these neighbouring states with respect to EU values and laws. It also raises questions about the appropriateness of the EU Neighbourhood Policy, which may have changed (Steven Blockmans, 2017. The Obsolescence of the European Neighbourhood Policy, CEPS, Brussels). 
The political geography of the territories directly close to the EU consists of three groups of countries, which in the EU official doctrine differ in terms of prospects of integration in the EU. The Balkans, of course, is the most privileged group that received the conditional promise of EU membership in 2000. Then, the countries of the Eastern Partnership (Ukraine, Georgia, Moldova), which adopted the EU proposal on deep and comprehensive free trade and a close political association, which nevertheless do not correspond to full membership in the EU, can be identified. The countries of the Middle East and North Africa (MENA) are at the third place with less probability of achieving an advanced level of integration in the EU than its eastern neighbours due to a variety of domestic and regional barriers or lack of interest from the countries concerned.

The Eastern Partnership countries (including Ukraine), if they are democratic countries, have the right to apply for full membership in the EU in accordance with Article 49 of the Treaty, as opposed to their southern neighbours.

The prospect of EU membership was recognized as the strongest external factor of internal political changes in the countries surrounding the EU. Scientists have argued that the quality of democratic governance in broader neighbourhoods is correlated with the strength of the incentives proposed by the Brussels Committee (Boerzel and Schimmelfennig, 2017). Countries with a credible prospect of joining the EU have larger democratic changes. It was suggested that the countries, with which the EU Association Agreements have been concluded, have different pace and level of democratic transformation, as compared to the candidate countries for joining the EU (Boerzel and Schimmelfennig, 2017). However, these arguments, in our opinion, should be clarified and investigated.

\section{Results and discussion}

3.1. Discourse and analysis of political governance

The analysis of politicalgovernancein the neighbouring countries of the EU in 2018 shows a much more diverse environment that ignores regional differences caused by both official EU enlargement and neighbourhood policy and the expectations of the scientific environment that the prospect of EU membership definitely creates political changes. The key point here is the belief in membership prospects. Almost two decades after the EU expanded its prospects for membership in the Balkans, the possibility of joining is still not visible even for the leaders of the region. After more than a decade after the start of the European Neighbourhood Policy, political realities are quite diverse, and leaders and less developed states in each region are confronted with the problem of regional stereotypes (see Table 1).

One of the most striking trends is the steady decline in the standards of political governance in all countries, for which the EU expands its membership perspective. Turkey's retreat from democracy is the brightest one but the Balkan candidates have also been affected by the

Table 1

Formed democracy rating in the EU's neighbouring countries

\begin{tabular}{|l|c|c|c|c|c|c|c|}
\hline & 2006 & 2008 & 2010 & 2012 & 2014 & 2016 & 2018 \\
\hline Albania & 7,25 & 7,5 & 7,55 & 7,25 & 6,7 & 6,95 & 7,1 \\
\hline Croatia & 9,1 & 8,85 & 8,5 & 8,4 & 8,45 & 8,4 & 8,4 \\
\hline Bosnia and Herzegovina & 6,8 & 6,7 & 6,5 & 6,4 & 6,35 & 6,3 & 6,1 \\
\hline Kosovo & H/A & H/A & 6,95 & 6,7 & 6,6 & 6,65 & 6,5 \\
\hline Macedonia & 7,55 & 7,75 & 7,95 & 7,6 & 7,2 & 6,65 & 6,5 \\
\hline Montenegro & 7,4 & 7,85 & 7,8 & 7,6 & 7,9 & 7,85 & 7,6 \\
\hline Serbia & 7,4 & 7,75 & 8 & 8,05 & 7,95 & 7,85 & 7,6 \\
\hline The Western Balkans & 7,58 & 7,73 & 7,61 & 7,43 & 7,31 & 7,24 & 7,13 \\
\hline Turkey & 7,05 & 7,05 & 7,65 & 7,65 & 7,55 & 7,25 & 5,6 \\
\hline Armenia & 5,2 & 6 & 4,92 & 5,25 & 5,35 & 5,23 & 5,1 \\
\hline Azerbaijan & 3,8 & 3,8 & 3,92 & 4,02 & 3,92 & 3,48 & 3,4 \\
\hline Belarus & 3,97 & 3,95 & 4,08 & 3,93 & 3,93 & 3,93 & 4,3 \\
\hline Georgia & 6,1 & 6,81 & 6,05 & 6,15 & 6,5 & 6,7 & 6,8 \\
\hline Moldova & 5,4 & 6,85 & 6,65 & 7,05 & 7,15 & 6,7 & 6,2 \\
\hline Ukraine & 7,1 & 7,35 & 7 & 6,1 & 6,1 & 6,75 & 6,9 \\
\hline The Eastern Partnership & 5,26 & 5,8 & 5,44 & 5,42 & 5,49 & 5,47 & 5,45 \\
\hline Algeria, Egypt & 4,23 & 4,27 & 4,37 & 4,3 & 4,8 & 4,8 & 4,8 \\
\hline Jordan & 4,1 & 3,98 & 4,02 & 3,92 & 4,1 & 4,03 & 4,4 \\
\hline Lebanon & 5,6 & 6,25 & 6,25 & 6,15 & 6 & 5,7 & 4,9 \\
\hline Morocco & 4,48 & 4,4 & 4,05 & 3,9 & 4 & 3,83 & 3,8 \\
\hline Tunisia & 3,38 & 3,95 & 3,78 & 3,85 & 5,8 & 6,3 & 6,5 \\
\hline The Southern Neighbourhood & 4,05 & 4,10 & 4,14 & 4,06 & 4,47 & 4,08 & 4,06 \\
\hline
\end{tabular}

Source: Bertelsmann Stiftung, Bertelsmann Transformation Index, 2018 
narrowing of democracy, and this process can extend, if not completely abolished, the process of their accession to the EU. Leaders in the region, according to political criteria, Serbia and Montenegro did not avoid regional trends, although their decline is lower compared to others - Albania, Bosnia and Herzegovina, Kosovo, and Macedonia. Recent events in Macedonia indicate improvements in political governance but this is not yet confirmed by new data (Bertelsmann Stiftung, 2018). Contrary to these negative trends are recent democratic achievements among the leaders of the Eastern Partnership during 2012-2016, which may be enigmatic to scholars. However, it was a period when free trade agreements were concluded, and this was a stimulus that had some weight. Ukraine not only improved the quality of democratic governance during this period but also overtaken the Balkan countries. The relatively positive quality of democracy in Ukraine against the backdrop of general authoritarianism in the regions bordering the EU and increasing geopolitical tensions in this period impresses (Freedom House, 2018).

One of the main manifestations of poor governance in the broader neighbourhood is the widespread corruption and impunity of officials. Weak rule of law and ineffective law enforcement bodies have become common practice in all different states and have allowed current officials to act with impunity during their term of office. It emerged that it is difficult to control corruption; however, data of the regions show that Georgia differs not only from its DCFTA partners but also from all Balkan states, including even the Balkan EU Member States, as evidenced by the achievements of ratings close to the average level of OECD countries and the EU. On the other hand, Moldova and Ukraine have a lower rating than the least effective Balkan countries (see Table 2).

Table 2

Corruption indicators in the Balkan countries and countries of the DCFTA among 180 countries of the world in 2017-2018

\begin{tabular}{|l|c|l|c|}
\hline \multicolumn{1}{|c|}{ Country } & Rating & \multicolumn{1}{c|}{ Country } & Rating \\
\hline Croatia & 57 & Turkey & 81 \\
\hline Bulgaria & 71 & Georgia & 46 \\
\hline Montenegro & 64 & Moldova & 122 \\
\hline Serbia & 77 & Ukraine & 130 \\
\hline Kosovo & 85 & Albania & 91 \\
\hline Bosnia & 91 & Macedonia & 107 \\
\hline
\end{tabular}

Source: Transparency International

A similar picture is formed in establishing the rule of law rating. Georgia is ahead of all Western Balkan states and has the best rating among the EU member states in the Balkan region (like in Croatia and much better than in Bulgaria). Ukraine, as the countries of the DCFTA, are close to Serbia, which, however, is not a regional leader.

The identified results challenge the assumption dominatingin political and scientific circles that a credible prospect of EU membership is steadily generating an internal environment conducive to democratic changes. The prospect of joining the EU did not contribute to the increased dynamics of democratization in the countries of the Western Balkans, which, after the initial strengthening of political rights and civil liberties in the early 2000s, regressed in the last decade in all respects. The reasons for this are well-known. From the EU side, the interest in stability in the region is caused by anxiety due to an increase in authoritarian tendencies (Bechev, D., 2016; BiEPAG, 2017; Richter, 2012). Most of the EU levers of influence regarding membership have been used to exert pressure on security officials in the Balkans to provide security by weakening hidden conflicts and moving towards normalization of good-neighbourly relations (Emerson, 2018) and by cooperation with EU countries' governments in issues of migration and fight against terrorism (Bechev, 2016).

Similarly, the cooperation of the Balkan governments helped to consolidate the so-called Balkans migration route in 2016, which strengthened the security of the EU borders and prevented criticism of the issues of internal political governance.

As a result, the retreat from democracy in the region was unobstructed, local leaders eliminated media freedom, established political control over nominally independent institutions and extreme forms of political bribery. In other words, the EU has consistently applied political pressure and sanctions concerning democratic regression in the region and sent an incorrect signal to the Balkan political elite that rushed to power to enjoy the benefits of public office (Pomorska and Noutcheva, 2017).

Inside these countries, there was no consistent, sustained social push aimed at crowding out a firm interest in the status quo, although casual social protests sometimes showed public dissatisfaction with the ruling political class. In general, the Balkan societies were too concerned about economic survival and wound healing after the conflicts of the 1990s to oppose the seizure of state resources by predatory elites. In addition, the EU's democratic mandate has suffered as a result of democratic challenges within the EU. The retreat from democracy in Hungary and Poland, as well as the reluctance of the EU to defend their fundamental political values, undermined the image of the EU as a propagandist of democracy abroad.

However, the experience of Ukraine indicates that a certain set of internal and regional factors can contribute to a push to democracy from the inside in the absence of a stimulus from the outside, although this process may be fragile and change to the opposite.

\subsection{Discourse and analysis of economic aspects of governance}

At the present stage of development of the world economic system, in conditions of uncertainty and 
instability of functioning, the key tools for ensuring the effectiveness of the implementation of socio-economic policy of the state are: the formation of an appropriate type of policy of modernizing the economy on the basis of the implementation of societal principles to determining the directions of structural and dynamic changes (Environmental Performance Index, 2016); the use of the principles of developing socio-economic systems, the application of which provides for the development and definition of a specific set of modernization measures regarding the implementation of functions of generating favourable conditions for targeted general economic growth, taking into account transformational changes to the adjustments to the target orientation of evolution.

The effectiveness of economic governance is assessed by the indicators of competitiveness of the national economy (Global Competitiveness Index, Corruption Perceptions Index, Human Development Index, Ease of Doing Business Index, Global Innovation Index, Index of Economic Freedom, Index of Globalization, life expectancy, Welfare Index, Global Peace Index, Press Freedom Index, SEDA (Sustainable Economic Development Assessment)); GDP dynamics; indicators of exports and imports of goods and services; the volume of foreign direct investment; the number of people engaged in economic activity; economic activity of the population. Let us consider and analyse the most important performance indicators.

The first indicator is the GDP per capita. The gap in GDP per capita is significant between the economies of the Balkan region, the economies of the DCFTA and the EU member states. The adjusted average GDP per capita in the Balkan countries is about $1 / 3$ of the average in all $28 \mathrm{EU}$ countries, which is about $1 / 5$ of the GDP per capita in the DCFTA countries.

The key issue for comparison is how far the countries of these regions have advanced in achieving the European level of economic efficiency since the 1990s. In the period from 1990 to 2016, the average figures of the EU countries increased 2.6 times. Thus, convergence for non-EU countries means an increase in GDP per capita faster than this value (see Table 3 ).

Analysing the table, we note that Albania and Turkey have made significant progress while Macedonia and Belarus have remained stable.

Reforms in the DCFTA countries are ineffective, and there were many political and economic reasons for this.

One of the decisive factors is, in particular, the relative severity of post-Soviet and post-Yugoslav economic shocks. Thus, the economic losses of the 1990s were smaller, although the regions had to suffer from the costs of wars that occurred after political disintegration. Countries of the DCFTA suffered significant economic losses immediately after independence. Ukraine was lagging behind the EU and other CIS countries (but only some of them benefited from the oil and gas sector). The low productivity of Ukraine is explained by a number of factors. First, the industrial structure of Ukraine was vulnerable after the collapse of the Soviet economy, moreover, many key supply chains, tied to the Russian industry, collapsed following independence and were finally destroyed by a conflict that began in 2014. What is more, Ukraine has suffered extremely unfavourable economic leadership and refusal of reform measures. Economic reforms have started only after the Maidan in 2014 and are still incomplete, and corruption remains widespread. The situation of the DCFTA countries shows the ineffectiveness of their economic governance.

The second indicator of the efficiency of economic selfgovernment is the definition of the Human Development Index. Most countries in these regions belong to a group of "high human development" countries, measured by the UNDP Human Development Index, which takes into account not only the economic level of the nation but also the health assessment by estimating the expected life expectancy at birth and the educational dimension, which is determined by the years of education (see Table 4). Montenegro is characterized by "very high human development", exceeding the indicators of such EU member states as Romania and Bulgaria, while Moldova is below with "moderate human development".

Table 3

Determination of adjusted GDP per capita in the Baltic States and the DCFTA in comparison of 1990 with 2016 (USD)

\begin{tabular}{|c|c|c|c|c|c|}
\hline Countries of the Balkan region & 1990 & 2016 & Countries of the DCFTA & 1990 & 2016 \\
\hline Albania & 2,72 & 11,54 & Georgia & 5,17 & 10,00 \\
\hline Bosnia & $\mathrm{n} / \mathrm{a}$ & 12,17 & Moldova & $\mathrm{n} / \mathrm{a}$ & 5,33 \\
\hline Macedonia & 5,25 & 14,52 & Ukraine & 6,76 & 8,27 \\
\hline Montenegro & $\mathrm{n} / \mathrm{a}$ & 17,63 & Average indicator & & 7,86 \\
\hline Serbia & $\mathrm{n} / \mathrm{a}$ & 14,51 & Other countries of the EAEU & & \\
\hline Average indicator & - & 13,40 & Armenia & 2,41 & 8,83 \\
\hline Croatia & $\mathrm{n} / \mathrm{a}$ & 23,42 & Belarus & 5,39 & 18,06 \\
\hline Turkey & 6,17 & 25,25 & Russia & 8,01 & 24,78 \\
\hline Average for EU countries & 14,99 & 39,61 & Kazakhstan & 8,44 & 25,28 \\
\hline & & & Average indicator & & 18,84 \\
\hline
\end{tabular}

Source: EBRD (2018), COM (2018) 
Georgia took a place next to the Balkan leader, Serbia, and Ukraine is approaching Bosnia, which is lagging behind other Balkan countries.

Table 4

Human Development Index, 2017

\begin{tabular}{|l|c|c|}
\hline \multicolumn{1}{|c|}{ Countries by categories } & $\begin{array}{c}\text { Human } \\
\text { Development } \\
\text { Index }\end{array}$ & $\begin{array}{c}\text { Country } \\
\text { rating }\end{array}$ \\
\hline Countries with the highest HDI & & \\
\hline Croatia & 0,827 & 45 \\
\hline Montenegro & 0,807 & 48 \\
\hline Romania & 0,802 & 50 \\
\hline \multicolumn{1}{|c|}{ Countries with high HDI } & & \\
\hline Belarus & 0,796 & 52 \\
\hline Bulgaria & 0,794 & 56 \\
\hline Serbia & 0,776 & 66 \\
\hline Georgia & 0,769 & 70 \\
\hline Turkey & 0,767 & 71 \\
\hline Albania & 0,764 & 75 \\
\hline Azerbaijan & 0,759 & 78 \\
\hline Bosnia and Herzegovina & 0,750 & 81 \\
\hline Ukraine & 0,743 & 83 \\
\hline Armenia & 0,742 & 84 \\
\hline \multicolumn{1}{|c|}{ Countries with moderate HDI } & & \\
\hline Moldova & 0,699 & 107 \\
\hline
\end{tabular}

Source: COM (2018), EBRD (2018)

The rating of the Balkan countries and the member countries of the DCFTA is more similar according to the Human Development Index than according to GDP per capita. This indicates that the level of human capital was much more stable than macroeconomics since relatively high educational achievements of the past were transferred to independent states better than economic structures.

The third indicator of the efficiency of economic self-government is an economic transition indicator, calculated by the European Bank for Reconstruction and Development (EBRD). Given that the regions have undergone a difficult transition from one type of the economy to another, the EBRD has developed a comprehensive set of transition indicators to assess how successful this process was. The results for several groups of countries, such as non-EU Balkan countries, three countries of the DCFTA, two most powerful southern Mediterranean states, and also, for the reference, new member states of the EU, were different. The average indicators of the Balkans and non-EU member countries of the DCFTA are practically the same and amount to 5.04 for the DCFTA countries (Ukraine, Georgia, Moldova) and less than 4.99 for the five Balkan states (Montenegro, Serbia, Macedonia, Albania, Bosnia). Kosovo, which is a special case, because it does not have the full attributes of statehood.

Both groups have a rather wide dispersion of indicators. The best indicator in Georgia is 5.41, ahead of Montenegro - 5.38, Serbia - 5.36, Macedonia - 5.26. The two less prosperous countries of the DCFTA, Moldova and Ukraine, are estimated to be approximately the same or slightly better than the less successful Balkan states (Albania and Bosnia) (Emerson, 2018; Popescu, Nicu, 2018).

Comparison can also be made with the "new" EU member states, among which the best result is in Estonia (7.58), and the worst - in Croatia (6.06) and Bulgaria (5.86). The two Mediterranean countries, Morocco (4.91) and Tunisia (4.53), are the weakest in comparison with the Balkans and the countries participating in the DCFTA.

The general conclusion of the analysis of indicators of the transformation of EBRD's economic self-government is that the countries of the Balkans and the DCFTA are closely correlated and may be averaged. For example, the best of the countries of the DCFTA (Georgia) can be compared with the best countries in the Balkans, while other states of the DCFTA (Moldova and Ukraine) can be compared to the average Balkan states.

The next macroeconomic indicator of the effectiveness of economic governance is the ease of doing business, which is calculated by the World Bank. The conditions for doing business in the regions are getting better, for example, Georgia and Macedonia catch up developed countries by this indicator and earned a place among the leading countries of the world in the World Bank's Ease of Doing Business Ranking (see Figure 1). However, the improvement is not homogeneous. The economies of Ukraine and Bosnia are the worst in each of the regions, in terms of the regulatory environment, and an unattractive place to stimulate investment and local business initiatives. There are certain assumptions in the calculation methodologies of the World Bank. For example, Macedonia's high ranking seems to be abnormal, as most of the polling components (not shown here) are much less favourable than the overall rating given in Figure 1.

Calculation of financial and economic ratings. There are several international rating agencies (Moody's, Standard \& Poor's, Fitch), which evaluate countries according to their creditworthiness, based on a set of financial and macroeconomic criteria, including political assessments that may affect creditworthiness.

Since the assessments of various rating agencies largely coincide, we present here only the current ratings of one agency - Moody's. The highest ratings of category A, or even larger AAAs, are granted to the strongest market economies or individual entities, which means that their securities are risk-free and highly profitable for the investor. No country in the Balkans and member countries of the DCFTA achieves this rating. All credit ratings of countries in categories $\mathrm{B}$ or $\mathrm{C}$ are considered risky or such that have speculative investment prospects, with gradations (Serbia-B3; Montenegro - B1; Albania-B1; Bosnia - B3; Georgia - B2; Moldova - B3; Ukraine - C).

Economic governance in accordance with EU standards. Since all the countries of the Balkan region 


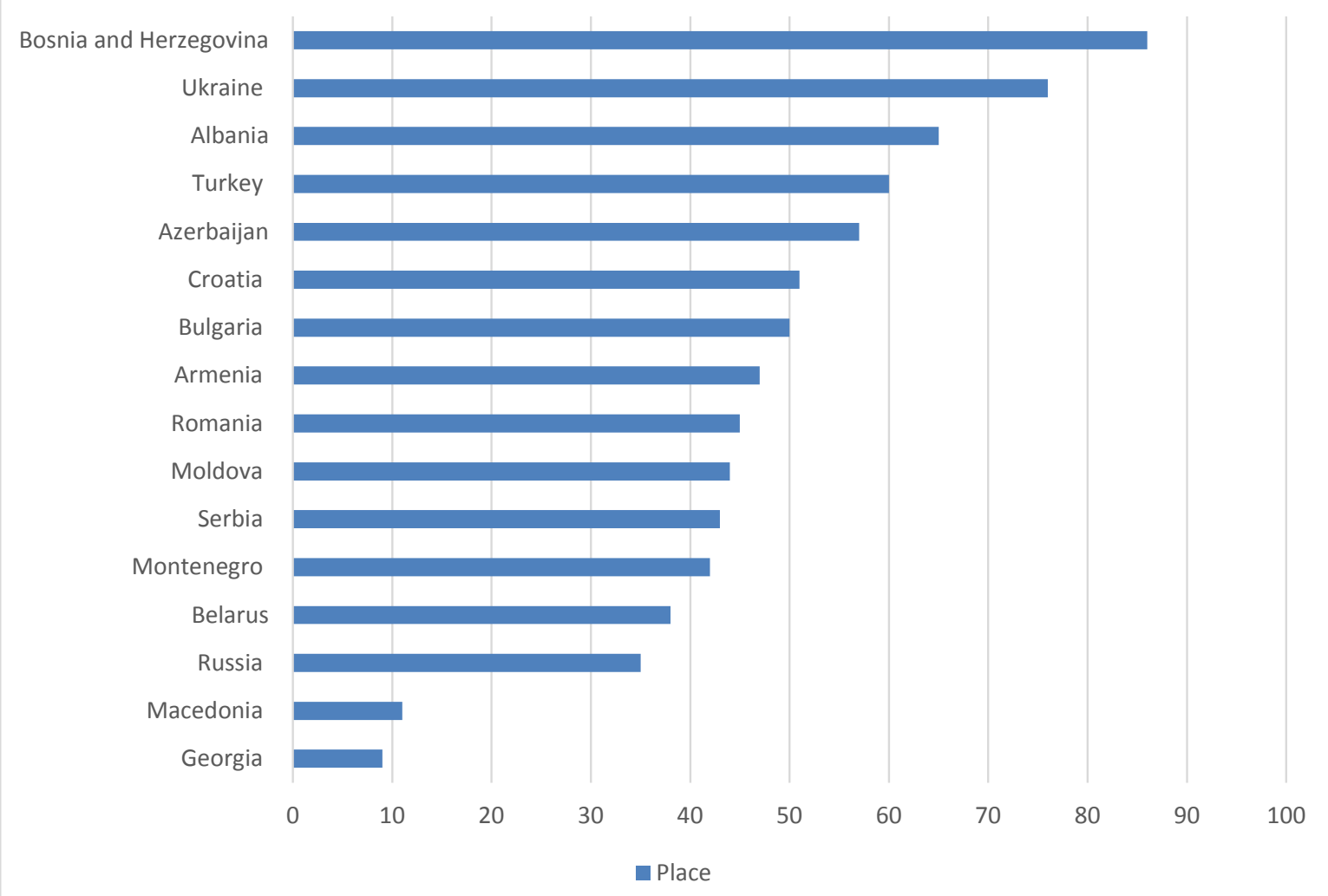

Figure 1. Ranking of countries by the Ease of Doing Business Index, 2017

Source: EBRD, 2018

Legend: Economy is evaluated for ease of doing business from 1 to 190. A high place in the ease of doing business ranking means that the regulatory environment is more favourable for the creation and operation of a local company

and the member countries of the DCFTA are seeking full membership of the EU, they have undertaken a commitment to comply with EU legislative acts and standards. Countries differ in the EU's readiness to recognize their membership prospects; however, all countries are developing programs for progressive compliance with EU requirements. For candidates for accession to the EU, this process consists of "chapters", which include EU policy blocs. They are informally similar to the materials of the Free Trade Agreement. And the EU's regular reports on progress in the Balkan countries, in Turkey, and in the member countries of the DCFTA cover the same issues to a large extent. This means that there is a well-structured base for comparison between all individual states.

The Commission favours the execution of this task through the methodology it has adopted to describe the essence of this complex material in a short "coded language". Each chapter in its assessments ends with an assessment of three degrees of readiness for EU membership with "certain", "moderate" or "good" levels of readiness.

In the economic ranking, Georgia occupies a higher place than the leading Balkan countries (Montenegro,
Serbia, and Macedonia) while Moldova and Ukraine outstripped Albania and Bosnia, for which the EU did not publish full data (Popescu, Nicu, 2018).

\section{Conclusions}

In general, we can say that high-quality democracy has not rooted in any country in both regions, where democratic breakthroughs are rarely followed by democratic upheavals. Political changes cause anxiety in all countries in the Balkans; nevertheless, they are less impressive in the countries of the DCFTA. The purpose of the political trajectories of the Balkan countries for joining the $\mathrm{EU}$ is that the region is approaching authoritarianism, and the challenges of political reform are serious. Political changes in the eastern neighbouring countries are fragile and occur in a less favourable geopolitical climate, so they are no less worthy of support and encouragement from the EU. So, it's time for the EU to justify its international reputation as a supporter of democracy, changing the situation as it is possible.

The effectiveness of economic governance was assessed by the indicators of competitiveness of the national economy (Global Competitiveness Index, Corruption 
Perceptions Index, Human Development Index, Ease of Doing Business Index, Global Innovation Index, Index of Economic Freedom, Index of Globalization, life expectancy, Welfare Index, Global Peace Index, Press Freedom Index, SEDA (Sustainable Economic Development Assessment)); GDP dynamics; indicators of exports and imports of goods and services; the volume of foreign direct investment; the number of people engaged in economic activity; economic activity of the population.

In practice, the EU applies an increasing number of common economic policy instruments for the Balkans and member countries of the DCFTA, in spite of the political (or rhetorical) differentiation between countries, given the categorization of membership prospects. There has been a convergence of the actual EU policy "outside the political radar" with respect to the two groups (for example, many technical measures are not proposed as a strategy). Agreements on the
Association and the DCFTA have raised the level of political and economic governance in Georgia, Moldova, and Ukraine at the level of countries of the Balkan region while the expansion process for the Balkan countries has not advanced.

The basis of the common economic and political development was the creation of deep free trade areas with the EU with a somewhat different meaning: this includes the Stabilization and Association Agreements (SAA) with the Balkans, the Customs Union with Turkey, and the DCFTA for Georgia, Moldova, and Ukraine. The main duty-free trading elements are supplemented by the Pan-Euro-Mediterranean Convention on Preferential Rules of Origin and the diagonal cumulation of value-added, common product standards, certain blocks of sectoral policies, including energy and transport policies, financial and investment mechanisms (EIB, EBRD, EU budget), etc.

\section{References:}

Balkans in Europe Policy Advisory Group (BiEPAG) (2017). The Crisis of Democracy in the Western Balkans. Authoritarianism and EU Stabilitocracy. Policy Paper, March. Retrieved from: http://www.biepag.eu/wp-content/ uploads/2017/03/BIEPAG-The-Crisis-of-Democracy-in-the-Western-Balkans.-Authoritarianism-and-EUStabilitocracy-web.pdf

Bechev, D. (2016). Europe's Refugee Crisis and the Balkans. Expert Brief, Alsharq Forum, 8 June. Retrieved from: http://sharqforum.org/2016/06/08/europes-refugee-crisis-and-the-balkans/

Bertelsmann Stiftung (2018). Bertelsmann Transformation Index, Gütersloh.

Blockmans, S. (2017). The Obsolescence of the European Neighbourhood Policy, CEPS and Rowman \& Littlefield International, October.

Börzel, Tanja A. and Frank Schimmelfennig (2017). Coming together or drifting apart? The EU's political integration capacity in Eastern Europe. Journal of European Public Policy, 24:2, 278-296.

EBRD (2018). Transition Report. London.

Emerson, M. (2018). The strategic potential of a Wider European Economic Area (WEEA), CEPS Commentary, CEPS, February.

European Commission (2018a). A credible enlargement perspective for and enhanced EU engagement with the Western Balkans.

Environmental Performance Index (2016). Global Metrics For The Environment. Retrieved from: https://www.epi.yale.edu

COM (2018). 65 final, Strasbourg, 6.2.2018. European Commission, '2018 Communication on EU Enlargement Policy', COM (2018) 450 final, 17 April 2018; to which are annexed "Accompanying documents" on Montenegro, Serbia, Macedonia, Bosnia, Albania, Kosovo and Turkey.

Freedom House (2018). Freedom in the World, 2018: Democracy in Crisis.

Paweł Dziekański (2017). Diversification synthetic indicator for evaluating the financial capacity of local government. the case of polish Voivodeships. Acta universitatis agriculturae et silviculturae mendelianae brunensis; volume 65 number 2. Retrieved from: https://doi.org/10.11118/actaun201765020611

Pomorska, K., Noutcheva, G. (2017). Europe as a Regional Actor: Waning Influence in an Unstable and Authoritarian Neighbourhood. Journal of Common Market Studies 55: (S1), 165-176.

Popescu, Nicu (2018). Why Georgia's Lessons for Russia Don't Apply in Ukraine, Carnegie Moscow Center, 13 February https://carnegie.ru/commentary/75483

Shevel, Oxana (2014). How Putin Turned Ukraine to the West, Monkey Cage, Washington Post, 29 October. Retrieved from: https://www.washingtonpost.com/blogs/monkey-cage/wp/2014/10/29/how-putin-turnedukraine-to-the-west/

Richter, Solveig (2012). Two at one blow? The EU and its quest for security and democracy by political conditionality in the Western Balkans.' Democratization, 19:3, 507-534.

Transparency International (2017). Corruption Perception Index, 2016, 25 January.

Vachudova, Milada Anna (2014). EU Leverage and National Interests in the Balkans: The Puzzles of Enlargement Ten Years On, Journal of Common Market Studies, 52:1, 122-138.

World Justice Project (2018). Rule of Law Index, 2017-2018. 